\title{
Rancang Bangun Sistem Keamanan Sepeda Motor Menggunakan Arduino Nano Dan Android Via Bluetooth
}

\author{
Maria Theresia Indriastuti ${ }^{1}$, Samsul Arifin ${ }^{2}$,Nur Fadhilah ${ }^{3}$, Tria Aprilianto ${ }^{4}$ \\ Institut Teknologi \& Bisnis Asia Malang \\ 1'maria@asia.ac.id, ${ }^{2}$ samsul@asia.ac.id, ${ }^{3}$ nurFadhilah@asia.ac.id, ${ }^{4}$ raptorapril@gmail.com
}

\begin{abstract}
ABSTRAK.Tingginya kasus pencurian sepeda motor menyebabkan kekhawatiran di kalangan pengguna sepeda motor. Pencurian sepeda motor bisa terjadi di mana saja dan kapan saja. Pencurian dapat dilakukan karena menggunakan kunci $\mathrm{T}$ atau menggunakan cairan kimia umum yang disebut setan. Meskipun pabrik telah menyediakan kunci stang dan kunci magnetik (seri sepeda motor baru) tetap saja pencurian dapat terjadi.

Sistem keamanan ini terdiri dari beberapa perangkat keras yang saling berhubungan yang menggunakan Arduino Nano, sensor getaran, modul SIM8001 untuk mengirim Short Message Service (SMS), smartphone android dan modul bluetooth sebagai komunikasi antara android dengan arduino, juga menggunakan modul relay sebagai penghubung antara Arduino dan listrik sepeda motor. Dari hasil pengujian sistem secara keseluruhan dan tingkat keamanan sistem, hal ini menunjukkan bahwa sistem mampu memberikan peringatan dalam bentuk SMS gateway dan menyalakan klakson ketika mendeteksi getaran atau mendeteksi perubahan. kondisi dari OFF ke ON di rumah kunci, dan sistem dapat mengubah kondisi OFF ke ON di kunci rumah dengan menggunakan ponsel android tanpa kunci kontak manual.
\end{abstract}

Kata Kunci: Keamanan Sepeda Motor, Alarm, Arduino Nano, Android, Bluetooth HC-05, Sensor Getar SW-420, SIM800L

ABSTRACT. The high cases of motorcycle theft causes worried among motorcycle users. Motorcycle theft can happen anywhere and anytime. The theft can be done because of using a T key or using a common chemical liquid called a demon. Although the factory has provided the handlebar lock and magnetic lock (the new motorcycle series) still the theft can happen. This security system consists of several interconnected hardware that is using Arduino Nano, vibration sensor, SIM8001 module to send Short Message Service (SMS), android smartphone and bluetooth module as communication between android with arduino, also using relay module as liaison between arduino and the motorcycle electricity. From the results of testing the system as a whole and the level of system security, it is indicating that the system is able to give a warning in the form of SMS gateway and turning on the horn when it is detecting a vibration or detecting the change of condition from OFF to ON on lock house, and system can change the condition of OFF to ON at home key by using android mobile phone without manual ignition key.

Keywords: Motorcycle Security, Alarm, Arduino Nano, Android, Bluetooth HC-05, Vibration Sensor SW-420, SIM800L

\section{PENDAHULUAN}

Maraknya kasus pencurian pada kendaraan motor khususnya sepeda motor yang menyebabkan resahnya para pengguna sepeda motor akan keamanan speda motor yang dimilikinya. Meskipun dari pabrikan sudah menyediakan kunci setang dan magnetic lock (sepeda motor keluaran baru) tetap saja pencurian bisa terjadi.

Seiring berjalannya waktu, pabrikan dan produsen pengamanan sepeda motor mengembangkan pengamanan ganda yaitu dengan adanya alarm tambahan pada sepeda motor menggunakan remot berbasis RF atau Radio Frequency. Itu pun pencuri bisa memanipulasi frekuensi tersebut. Pada penelitian sebelumnya (Aji D.K, 2018) telah melakukan pembuatan sistem keamanan motor yang dilengkapi dengan Bluetooth dengan aplikasi android sama dengan penelitian (Kholilah, Ika \& Al Tahtawi A.R, 2016). Begitu juga dengan penelitian (Suwanto, Thomas. dkk. 2016) juga masih menggunakan Bluetooth sebagai alat komunikasi motor dengan smartphone android. Pada penelitian ini sistem keamanan yang dirancang sedikit memiliki kesamaan dengan tiga penelitian sebelumnya, akan tetapi ada beberapa perbedaan diantaranya pada penelitian ini sudah dilengkapi dengan modul GSM (Global System for Mobile Communication). Dengan adanya modul GSM ini maka ketika pemilik kendaraan sedang berada jauh dari tempat motor maka tetap dapat melakukan monitoring. Perbedaan lainnya terletak pada desain software dan hardware. 
Oleh karena itu, di rancanglah "Rancang Bangun Sistem Keamanan Sepeda Motor Berbasis Arduino Nano dan Android via Bluetooth" sebagai keamanan tambahan pada sepeda motor dan sebagai pengganti alarm tambahan yang menggunakan RF (Radio Frequency).

\section{METODE PENELITIAN}

Dalam penelitian ini diperlukan beberapa teori pendukung diantaranya sebagai berikut:

\section{A. Arduino Nano}

Arduino Nano adalah salah satu varian mikrokontroler Arduino yang kecil dengan berat sekitar 5 gram, lengkap, dan breadboard-friendly yang berbasis Atmega328 (Arduino Nano 3.x) atau Atmega168 (Arduino Nano 2.x). Ia memiliki fungsi yang kurang lebih sama dengan Arduino Duemilanove, tapi dalam kemasan yang berbeda. Nano bekerja dengan kabel Mini-B USB dan didesain oleh Gravitech. (www.arduino.cc)

\section{B. Arduino IDE}

Arduino Integrated Development Environtment (IDE) adalah sebuah software yang dibuat oleh Arduino yang khusus digunakan perangkat Arduino. Arduino IDE berguna untuk menuliskan program, compile program dan melakukan upload ke dalam memory mikrokontroller. Selain itu juga terdapat serial monitor yang dapat digunakan untuk melihat jalannya program yang berjalan pada perangkat arduino. Berkut tampilan Arduino IDE.(www.arduino.cc)

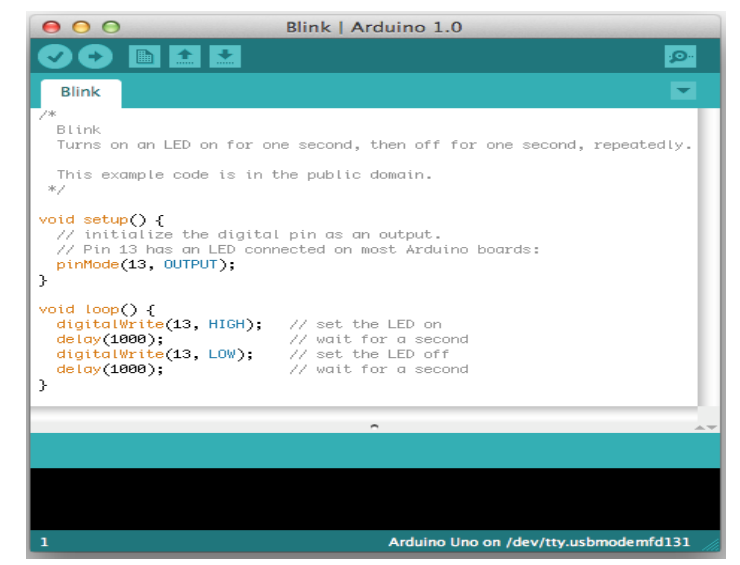

C. Android

Gambar 1. Tampilan Arduino IDE(www.arduino.cc)

Android adalah sebuah sistem operasi untuk perangkat mobile berbasis linux yang mencakup sistem operasi, middleware, dan aplikasi. Di dunia ini terdapat dua jenis distributor sistem operasi Android. Pertama yang mendapat dukungan penuh dari Google atau Google Mail Services (GSM) dan kedua adalahyang benarbenar bebas distribusinya tanpa dukungan langsung Google atau dikenal sebagai Open Handset Distribution (OHD). Pada saat ini kebanyakan vendor-vendor smartphone sudah memproduksi smartphone berbasis android, antara lain HTC, Motorola, Samsung, LG, Sony Ericsson, Acer, Nexus, Nexian,IMO, dan masih banyak lagi vendor smartphone di dunia yang memproduksi android. Hal ini karena android itu adalah sistem operasi yang open source sehingga bebas didistribusikan dan dipakai oleh vendor manapun. Pesatnya pertumbuhan android selain faktor yang disebutkan sebelumnya adalah karenaandroid itu sendiri adalah platform yang sangat lengkap baik sistem operasinya, aplikasi dan Tool Pengembangan, Market aplikasi android serta dukungan yang sangat tinggi dari komunitas open source di dunia, sehingga android terus berkembang pesat baik dari segi teknologi maupun dari segi jumlah device yangada di dunia. (Rahmawati, Suci. 2015)

\section{Modul Bluetooth HC-05}

Bluetooth Module HC-05 merupakan module komunikasi nirkabel pada frekuensi $2.4 \mathrm{GHz}$ dengan pilihan koneksi bisa sebagai slave, ataupun sebagai master. Sangat mudah digunakan dengan mikrokontroler untuk membuat aplikasi wireless. Interface yang digunakan adalah serial RXD, TXD, VCC dan GND. Built in LED sebagai indikator koneksi bluetooth. (Aji D.K. 2018) 


\section{E. Modul Sensor Getar SW-420}

Modul sensor ini akan menghasilkan keluaran logika HIGH pada saat mendeteksi vibrasi / getaran, menggunakan komponen pendeteksi getaran SW-420 yang berekasi terhadap getaran. Pada kondisi statis / tanpa getaran, komponen elektronika ini berfungsi seperti saklar yang berada pada kondisi menutup (normally closed), sebaliknya pada kondisi terguncang ada getaran maka saklar akan membuka.(Aji D.K. 2018)

F. Modul Relay

Modul Relay adalah rangkaian kombinasi antara relay dengan transistor yang digunakan untuk memutus atau menghubungkan sumber tegangan yang digunakan untuk mensupplai klakson. Modul Relay ini menggunakan susunan rangkaian dengan logika High sehingga untuk mengaktifkannya maka cukup dengan memberi sinyal High (5 Volt) pada pin inputan Modul Relay.(Aji D.K. 2018)

\section{G. Modul SIM800L}

SIM8001 adalah solusi pita ganda GSM / GPRS lengkap dalam modulSMT yang dapat ditanamkan di aplikasi pengguna. Dengan antar muka standarindustri, SIM8001 memberikan performa GSM / GPRS 900 / 1800MHz untuksuara, SMS, Data, dan Faks dalam faktor bentuk kecil dan dengan konsumsidaya rendah. Dengan konfigurasi kecil $24 \mathrm{~mm} \times 24 \mathrm{~mm} \times 3 \mathrm{~mm}$, SIM8001 dapatmemenuhi hampir semua persyaratan ruang dalam aplikasi pengguna, terutamauntuk permintaan desain yang ramping dan padat.

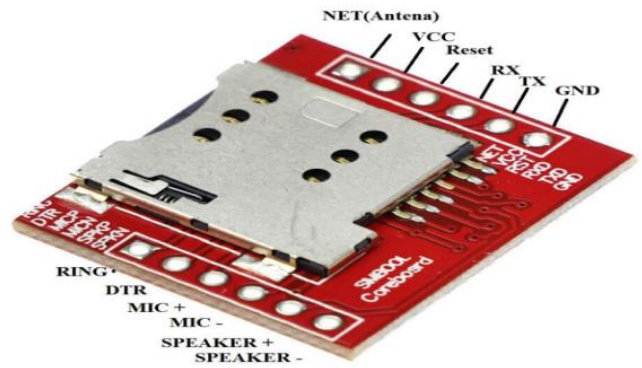

Gambar 2. Modul SIM800L

Adapun fitur dari modul GSM SIM8001 adalah sebagai berikut :

1. Empat pita 850/ 900/ 1800/ $1900 \mathrm{MHz}$.

2. Modul daya secara otomatis booting, pada jaringan rumahan.

3. Mendukung jaringan : Empat pita jaringan global.

4. Ukuran modul : 2.5 x 2.3cm kelas 1 (1 W @ 1800/1900MHz).

5. TTL port serial untuk port serial, anda mampu menghubungkan secara langsung ke mikrkontroler. Tidak memerlukan MAX232 karena konsumsidaya rendah : 1.5mA (mode tidur).

6. Sinyal diatas papan akan menyala semua. Ia akan berkedip perlahan saatada sinyal, apabila berkedip sangat cepat maka tidak ada sinyal.(Kautsar, Nohan Aryang. 2018)

\section{HASIL DAN PEMBAHASAN}

\section{A. Perancangan Hardware}

1. Perancangan Rangkaian Modul Bluetooth HC-05

Perancangan modul bluetooth digunakan untuk menerima data informasi yang dikirim dari handphone.

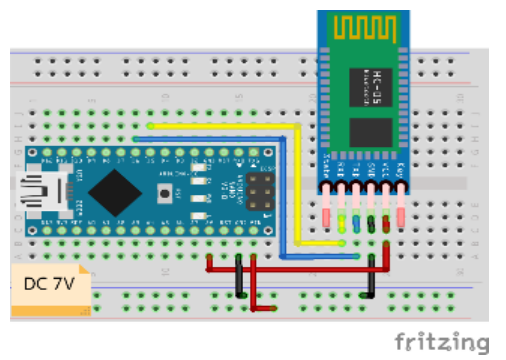

Gambar 3. Perancangan Modul Bluetooth HC-05 
Konfigurasi pin Modul Bluetooth HC-05 dengan Arduino Nano :

1. VCC: Dihubungkan ke tegangan Positif (+) 5V.

2.GND: Dihubungkan ke tegangan Negatif (-) atau ground.

3.TXD: Dihubungkan ke port D6.

4.RXD: Dihubungkan ke port D5.

2. Perancangan Rangkaian Modul Sensor Getaran SW-420

Pada perancangan modul ini digunakan sebagai pendeteksi getaran, sehingga jika ada getaran maka modul ini mengeluarkan output data digital HIGH. Tingkat getaran bisa dirubah ke sensitifannya dengan memutar potensio yang sudah tersedia pada modul ini.

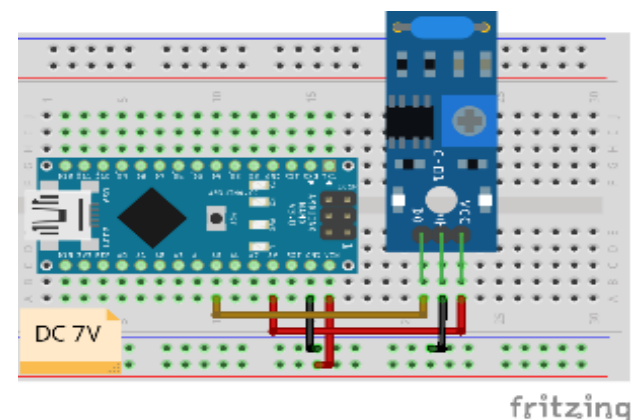

Gambar 4. Perancangan Modul Sensor Getaran SW-42

Konfigurasi pin Modul Sensor Getar SW-420 dengan Arduino Nano :

1. VCC: Dihubungkan ke tegangan Positif (+) 5V.

2.GND: Dihubungkan ke tegangan Negatif (-) atau ground.

3.DO: Dihubungkan ke port A5.

3. Perancangan Rangkaian Modul Sim800L

Perancangan modul Sim800L ini digunakan untuk mengirim SMS ke pengendara bahwa adanya getaran pada sepeda motor.

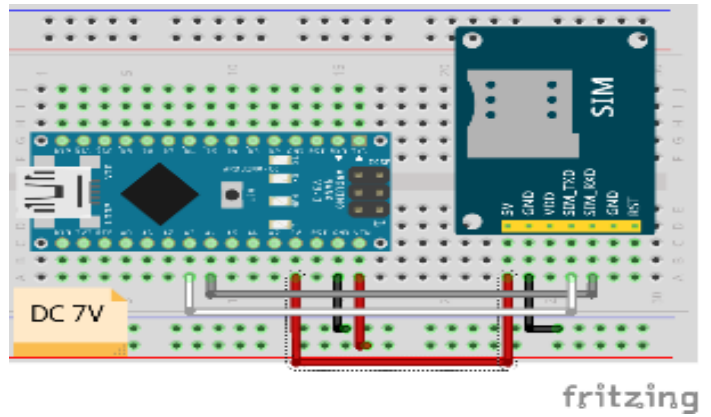

Gambar 5. Perancangan Modul Sim8001

Konfigurasi pin Sim800L dengan Arduino Nano :

1.5V: Dihubungkan ke tegangan Positif (+) 5V.

2.GND: Dihubungkan ke tegangan Negatif (-) atau ground.

3.SIM_TXD: Dihubungkan ke port A3.

4.SIM_RXD: Dihubungkan ke port A4.

4. Perancangan Rangkaian Modul Relay

Dalam perancangan modul relay ini digunakan untuk menghidupkan dan mematikan 3 actuator pada sepeda motor yaitu aliran listrik ke kunci kontak, mesin (CDI), dan klakson.

1. Perancangan Modul Relay untuk aliran listrik kunci kontak

Pada Bagian ini untuk mengontrol aliran listrik kunci kontak sepeda motor lebih jelasnya pada gambar berikut. 


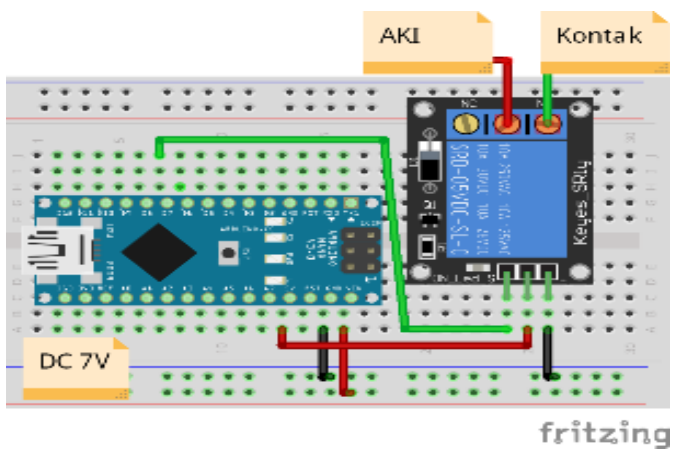

Gambar 6. Perancangan Modul Relay untuk Kunci Kontak

Konfigurasi pin Modul Relay dengan Arduino Nano :

a. VCC: Dihubungkan ke tegangan Positif (+) 5V.

b.GND: Dihubungkan ke tegangan Negatif (-) atau ground.

c. IN: Dihubungkan ke port D7.

d.C (common): Dihubungkan ke kontak sepeda motor (paralel dengan kunci kontak).

e. NO : Dihubungkan ke kontak sepeda motor (paralel dengan kunci kontak)

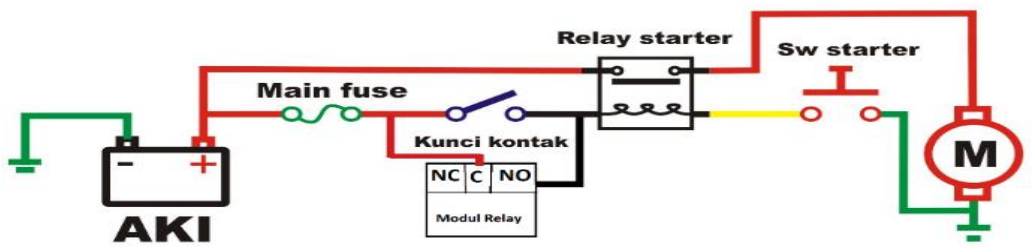

Gambar 7. Perancangan Aliran Listrik Kunci Kontak

2. Perancangan Modul Relay untuk aliran listrik mesin CDI

Pada Bagian ini untuk mengontrol aliran listrik pada mesin yaitu sistem pengapian atau di bagian CDI sehinga tanpa adanya catu daya dari aki maka sepeda motor tidak akan bisa hidup. Untuk lebih jelasnya pada gambar berikut.

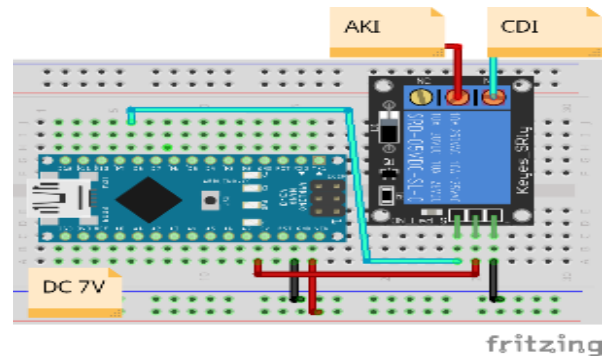

Gambar 8. Perancangan Modul Relay untuk CDI

Konfigurasi pin Modul Relay dengan Arduino Nano :

a. VCC: Dihubungkan ke tegangan Positif (+) 5V.

b. GND: Dihubungkan ke tegangan Negatif (-) atau ground.

c. IN: Dihubungkan ke port D8.

d.C (common): Dihubungkan ke CDI dari jalur aki.

e. NO : Dihubungkan dari jalur aki menuju ke CDI.

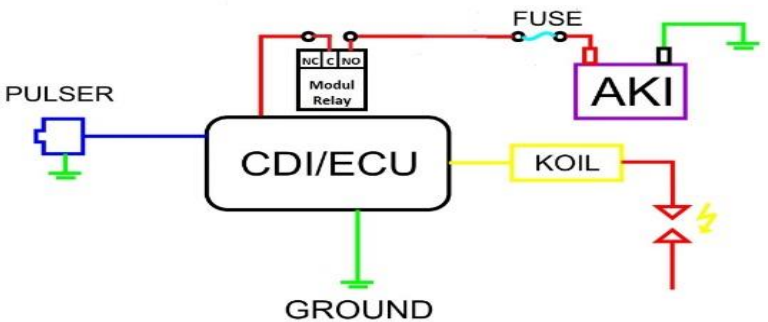

Gambar 9. Perancangan Aliran Listrik untuk CD 
3. Perancangan Modul Relay untuk aliran listrik klakson

Pada Bagian ini untuk membunyikan klakson pada sepeda motor sehinga saat relay ini diberikan logika HIGH maka klakson akan berbunyi. Untuk lebih jelasnya pada gambar berikut.

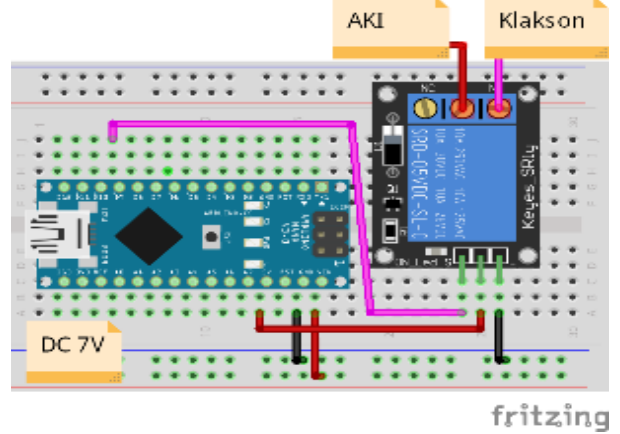

Gambar 10. Perancangan Modul Relay untuk Klakson

Konfigurasi pin Modul Relay dengan Arduino Nano :

a. VCC: Dihubungkan ke tegangan Positif (+) 5V.

b. GND: Dihubungkan ke tegangan Negatif (-) atau ground.

c. IN: Dihubungkan ke port D9.

d.C (common): Dihubungkan ke tegangan Positif (+) dari jalur aki(paralekan dengan switch / tombol klakson).

e. NO : Dihubungkan ke klakson (paralekan dengan switch / tombol klakson).

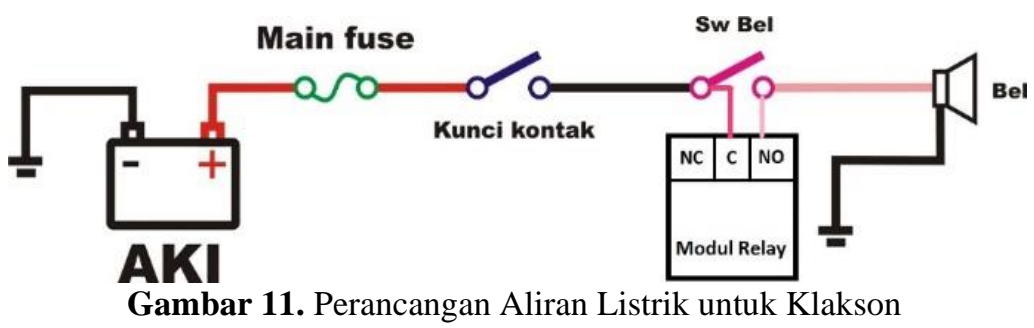

5. Perancangan Keseluruhan Sistem

Rangkaian keseluruhan sistem ini menggabungkan rangkaian dari sub-bab yang sudah di bahas sebelumnya. Yaitu terdiri dari Arduino Nano, Modul Bluetooth HC-05, Modul Sensor getaran SW-420, Modul Sim800L dan 3 Channel Modul Relay. Berikut gambar rangkaian secara keseluruhan.

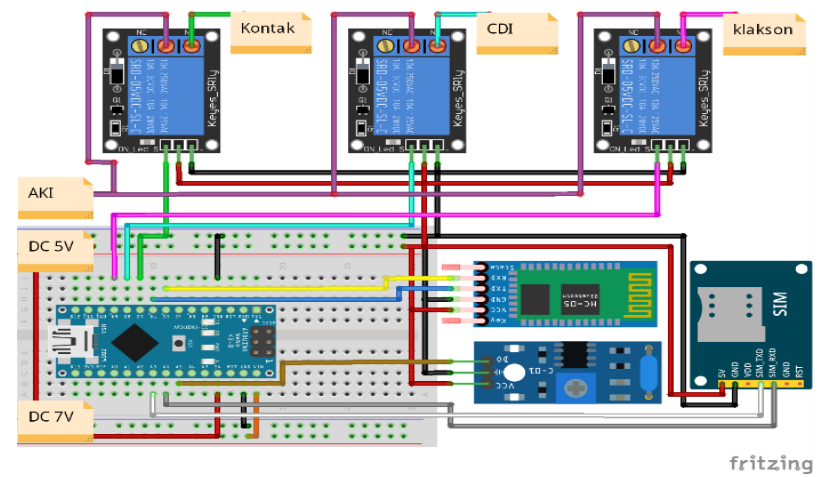

Gambar 12. Perancangan Keseluruhan Sistem

B. Perancangan Software

1. Flowchart Konnikasi Android dengan Arduino 
Adapun flowchart proses komonikasi arduino dengan android di bagi dua yaitu:

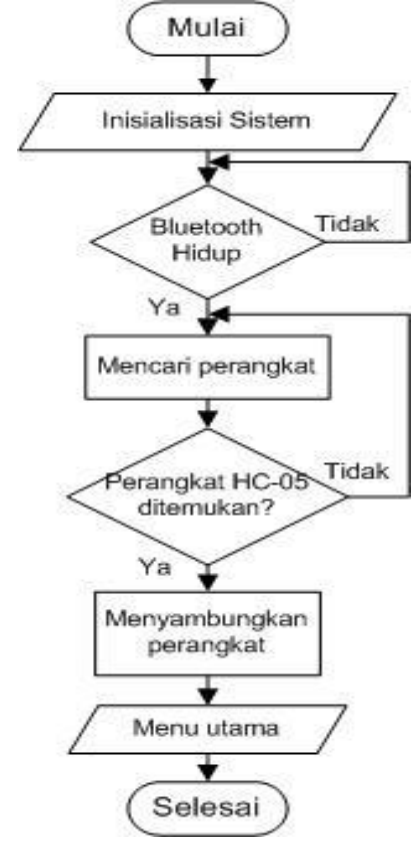

Gambar 13. Flowchart koneksi Android dengan Bluetooth

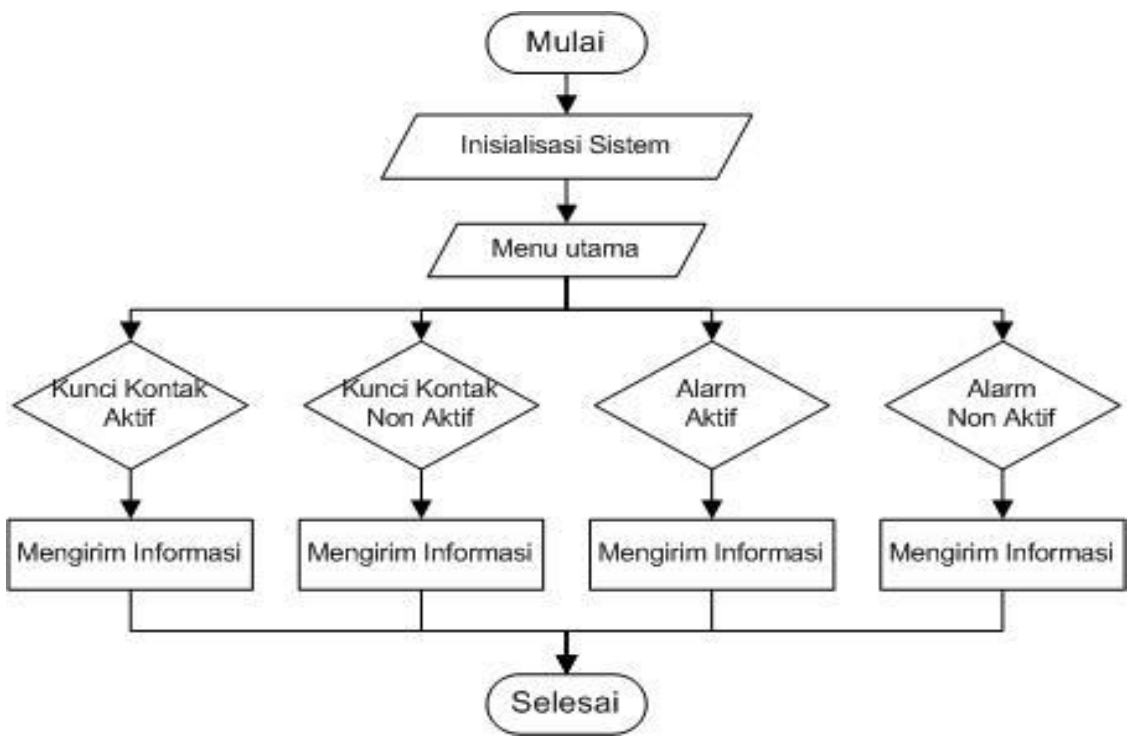

Gambar 14. Flowchart Pemilihan dan Mengirim Informasi

2. Flowchart Kunci Kontak berikut.

Adapun flowchart proses megaktifkan / menonaktifkan kunci kontak dapat ditunjukkan pada gambar 


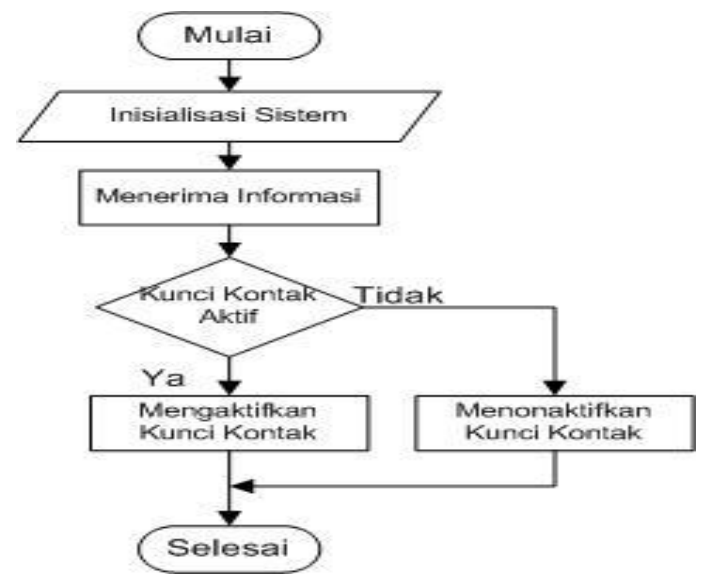

Gambar 15. Flowchart Mengaktifkan atau menonaktifkan Kunci Kontak

3. Flowchart Alarm

Adapun flowchart proses alram aktif atau non aktif dapat ditunjukkan pada gambar berikut.

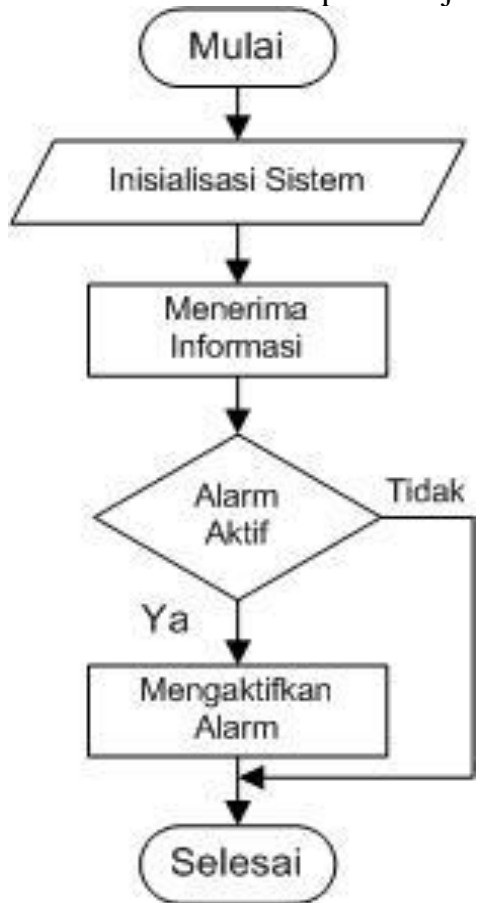

Gambar 16. Flowchart Meaktifkan dan Nonaktifkan Alarm 


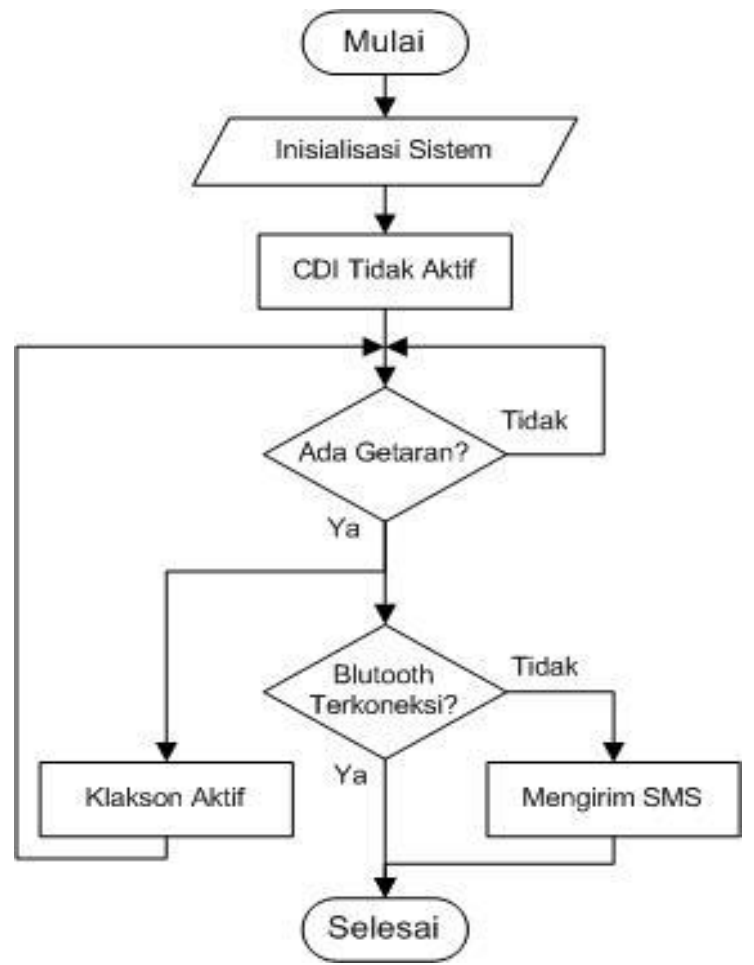

Gambar 17. Flowchart Saat ada Getran

C. Perancangan Mekanik

1. Perancangan Mekanik Alat

Alat ini dirancang dalam 1 bagian sistem yang berisi Modul Bluetooth HC-05, Modul Sensor Getaran SW-420, Arduino Nano, Modul Sim800L dan 3 channel modul relay. Alat akan dipasang pada sepeda motor sehingga diperlukan bentuk mekanik seefisien mungkin.

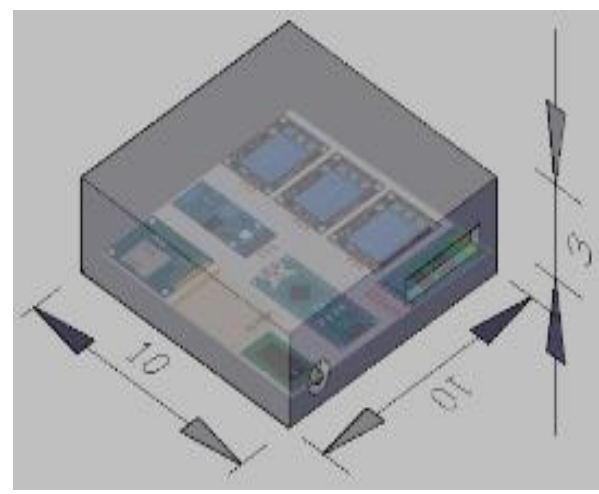

Gambar 18.Perancangan Mekanik Alat

Gambar di atas menunjukkan rancangan mekanik alat dengan panjang $10 \mathrm{~cm}$, lebar $10 \mathrm{~cm}$ dan tinggi 3 $\mathrm{cm}$. Disediakan lubang untuk jack konektor untuk catu daya dari aki, dan lubang berbentuk persegi panjang untuk keluarnya kabel sebagai penghubung kelistrikan sepeda motor. juga kabel untuk baterai tambahan. 


\section{Perancangan Letak Alat}

Untuk perancangan letak alat pada sepeda motor akan di letakkan di bawah jok/sadel, tepatnya (kotak merah) pada gambar di bawah ini. Sehingga alat tidak terlalu jauh dari aki dan sistem kelistrikan lainnya.

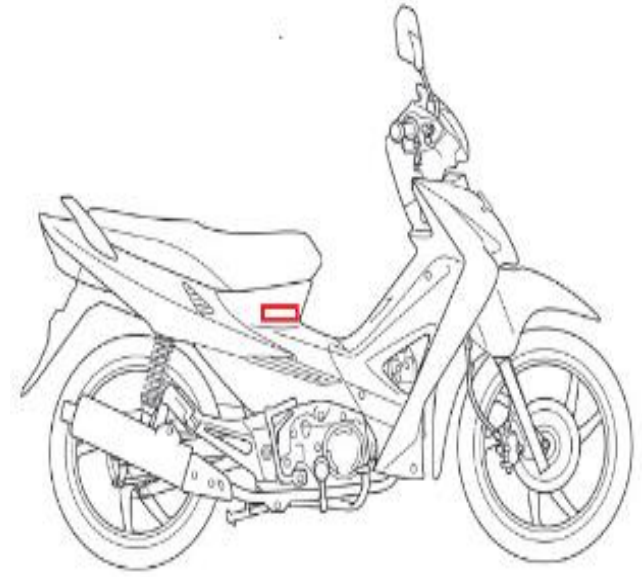

Gambar 19. Letak Alat pada Motor

\section{Hasil dan Analisa}

Pada saat menekan tombol Alarm ON maka sistem akan membaca data sensor getar dan memutus aliran listrik menuju mesin sehingga mesin tidak dapat di nyalakan. Begitu juga saat menekan tombol Alarm OFF maka sistem akan berhenti membaca data sensor getar dan akan menghubungkan kembali aliran listrik menuju mesin.

Jika dalam kondisi Alarm ON jika ada getaran maka sistem akan membunyikan klakson selama 20 detik serta akan mengirim SMS untuk pengguna. Setelah 20 detik sistem akan membaca data sensor getar kembali, jika masih mendeteksi adanya getaran maka klakson akan kembali bunyi selama 20 detik serta akan mengirim SMS.

Sebaliknya jika kondisi Alarm ON tetapi tidak mendeteksi getaran maka sistem tidak akan membunyikan klakson serta tidak akan mengirim SMS untuk pengguna, dan mesin tetap tidak dapat di nyalakan di karenakan saat Alarm ON mesin akan memutuskan aliran listrik menuju mesin.

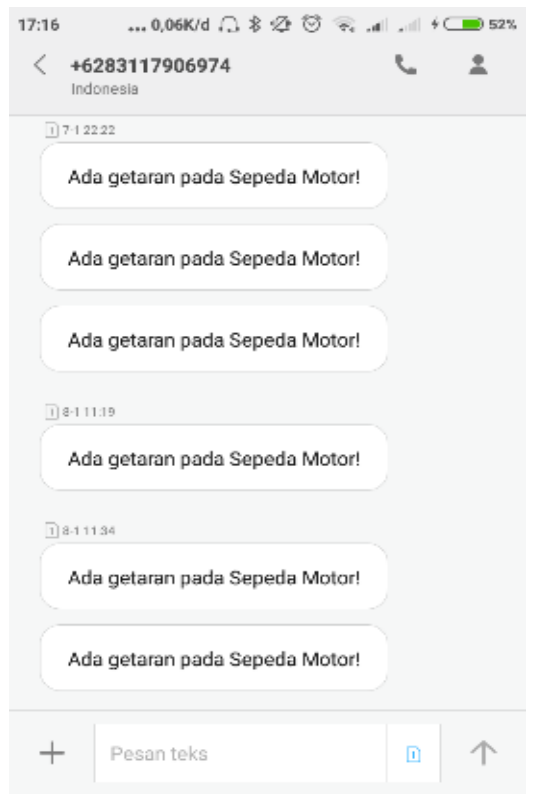

Gambar 20. Penerimaan SMS pada saat mendeteksi getaran 
Tabel 1. Hasil pengujian Kunci Kontak

\begin{tabular}{|c|c|c|}
\hline & $\begin{array}{c}\text { Kunci Kontak } \\
\text { Aplikasi ON }\end{array}$ & $\begin{array}{c}\text { Kunci Kontak } \\
\text { Aplikasi OFF }\end{array}$ \\
\hline Kunci KontakManual ON & Mesin Menyala & Mesin Menyala \\
\hline Kunci KontakManual OFF & Mesin Menyala & Mesin Tidak Menyala \\
\hline
\end{tabular}

Tabel 2. Hasil pengujian Alarm

\begin{tabular}{|c|c|c|c|c|c|c|}
\hline \multirow{2}{*}{} & \multicolumn{3}{|c|}{ Alarm ON } & \multicolumn{3}{c|}{ Alarm OFF } \\
\cline { 2 - 7 } & Klakson & SMS & Mesin & Klakson & SMS & Mesin \\
\hline Ada Getaran & Menyala & Diterima & $\begin{array}{c}\text { Tidak } \\
\text { menyala }\end{array}$ & $\begin{array}{c}\text { Tidak } \\
\text { menyala }\end{array}$ & $\begin{array}{c}\text { Tidak } \\
\text { diterima }\end{array}$ & Dapat Menyala \\
\hline Tidak Ada Getaran & Tidak & Tidak & Tidak & Tidak & Tidak \\
menyala & diterima & menyala & menyala & Dapat Menyala \\
\hline Kontak Manual ON & Menyala & Diterima & $\begin{array}{c}\text { Tidak } \\
\text { menyala }\end{array}$ & $\begin{array}{c}\text { Tidak } \\
\text { menyala }\end{array}$ & $\begin{array}{c}\text { Tidak } \\
\text { diterima }\end{array}$ & Dapat Menyala \\
\hline Kontak Manual OFF & Tidak & Tidak & Tidak & Tidak & Tidak & Tidak Menyala \\
& menyala & diterima & menyala & menyala & diterima & \\
\hline
\end{tabular}

\section{KESIMPULAN DAN SARAN}

Dari hasil pembahasan perancangan sistem dapat dibuat kesimpulan, yaitu:

1. Sistem dapat terkoneksi dengan handphone menggunakan koneksi bluetooth dengan jarak maksimal 9 meter tanpa halangan dan 7 meter dengan halangan.

2. Sistem dapat memutus aliran istrik ke mesin pada saat alarm aktif sehingga mesin tidak dapat menyala selama alarm masih dalam keadaan aktif.

3. Sistem dapat mendeteksi adanya getaran saat alarm aktif dan berhasil mengirim SMS ke tujuan serta membunyikan klakson.

4. Pada rumah kunci sepeda motor sistem dapat mendeteksi adanya perubahan kondisi OFF ke kondisi ON, jika alarm dalam kondisi aktif sistem berhasil mengirim SMS ke tujuan serta membunyikan klakson.

5. Aplikasi android sistem dapat terinstal dengan baik di beberapa versi android yaitu kitkat, lollipop, marsmellow dan nougat

Saran untuk pengembangan selanjutnya adalah dengan menambahkan fitur GPS sebagai alat pelacak posisi kendaraan.

\section{DAFTAR RUJUKAN}

Aji D.K. 2018, Sistem Pengaman Sepeda Motor Dengan Arduino Berbasis Android,(Online), (http://eprints.ums.ac.id/66662/4/FIX\%20upload.pdf).

Kautsar, Nohan Aryang. 2018, Sistem Peringatan Dini Banjir Berbasis SMS GSM, STMIK AKAKOM YOGYAKARTA 
Kholilah, Ika \& Al Tahtawi A.R. 2016, Aplikasi Arduino-Android untuk Sistem Keamanan Sepeda Motor, (Online), Vol. 1, no. 1, (http://jtera.polteksmi.ac.id/index.php/jtera/article/download/9/7, diakses 22 April 2017).

Rahmawati, Suci. 2015, Simulasi Membuka, Menutup Pintu dan Menghidupkan Mesin Mobil Menggunakan Android, (http://eprints.polsri.ac.id/id/eprint/1784.

Suwanto, Thomas. dkk. 2016, Jurnal Ilmiah Widya Teknik, Aplikasi Kontrol Sepeda Motor Menggunakan Bluetooth Pada Smartphone Android, (Online), Vol. 15, no. 2,

(http://journal.wima.ac.id/index.php/teknik/article/view/918, diakses 18 April 2017).

https://www.arduino.cc/ 